\title{
FINANCIAL PROVISION OF CONTRACT BY LIMITING PRICE OF PRODUCTS
}

\author{
Chernenko A.F. \\ South Urals State University \\ SUSU \\ Chelyabinsk city, Russia \\ 2052@bk.ru
}

\author{
Afonina O.A. \\ Central research institute of chemistry and mechanics \\ Moscow city, Russia \\ Xano4ka@yandex.ru
}

\begin{abstract}
In some cases, the product price, which is the output price for the enterprise, does not reflect the actual costs of the product. In this way the organization is to minimize its losses that appeared due to the discrepancy of established and real figures. In case of production output in accordance with the requirements, defined by the customer, the specific features of price formation do not allow disposing the product at a price and with the cost effectiveness value higher than one installed by the customer, overstate or understate production output costs. It is shown that existing calculation methods can not be applied by organizations that work with the directive contract. In the article, the backflush costing approach that corresponds to the normative legal acts regulating the economic components formation in the sphere of directive planning, is considered. If conditions, proved in this article, are met, the organization will reach maximum possible profit, operating revenue indicators and an optimum cost level that will provide the covering of all the production expenses. The developed method of the contract price formation in case of limitation of its cost has been successfully implemented in the system of research and industrial enterprises of military-industrial complex of the Russian Federation. This method provides the suitable combination of the contract price and the gross profit for both subjects of economic activity - the customer and the enterprise. The research provided by the authors of the article provides a scientific contribution to the evolution of the backflush calculation approach and calculation of production costs that has various limitations of its market price. Developed method allows also executing the actual cost accounting till the moment of the accounting reporting period and correction of financial results basing on customers' conclusions.
\end{abstract}

Keywords-backflush calculation, planning, contract price, order, wage costs, costs Introduction

\section{INTRODUCTION}

In some cases, the product price which is the output price for the enterprise does notreflect the actual costs of the product. In this way the organization is to minimize its losses that appeared due to the discrepancy of established and real figures. For example, it is possible if:

- product cost can not be higher than market prices;

- realization of output is urgent;
- the price is fixed by regulatory acts;

- the price is fixed by the customer.

In the last case, if the product output is performed in accordance with the requirements, defined by the customer, the price formation peculiarities are not to dispose the product at a price and with the cost effectiveness value higher than one specified by the customer, overstating or understating production output costs

The most suitable example of price definition in accordance with the customer's requirements can be the activity of military-industrial complex in terms of government orders.

Enterprises that are the only possible contractors of execution of the government defense order have no right to refuse its fulfillment, in consequence of which they should conduct measures on production cost value formation and its components, basing on figures stated by the government, and also undertake actions on adjustment of the actual cost efficiency level to values stated by the government.

The specific feature of such work is the complete report to the governmental customer on costs that are incurred in terms of the order execution, nonexistence of inappropriate expenditures that are earmarked for the order; and also elimination of possibility to increase the level of gross profit.

The last peculiarity consists in the fact that in the process of the defense order execution, the profit is calculated as an exposure to costs that were earmarked in terms of the contract performance or taken as a fixed value, and the price of production is calculated as a sum of actual costs and profit that depends on its level. In this way, in case of lowering the cost level, the production price lowers accordingly. While in case of any nondefence production output, the Contractor receives the additional marginal profit by means of lowering its' costs' level.

In this way, there is a problem to develop the calculation methodology for the contract that provides the most suitable composition of both the contract price and gross profit for two economic subjects - the Customer and the Contractor enterprise. 
The carried out analysis of the calculation methodology showed that existing calculation methods are inadequate for enterprises with elements of directive planning, as it does not include the above-mentioned specific accounting features. This obstacle leads to the necessity to elicit the additional methods of calculation for production output that are close to the external conditions.

The analysis of existing methods of cost accounting and calculation showed that only the order method meets the requirements of the Russian legislation to determine the composition of costs for the Defense industry production, supplied under the state defense order. However, cost accounting by this method assumes direct costing with the subsequent formation of the cost price and financial results by order. This does not reflect the specifics of the defense industry, which involves the costs calculation, based on a previously known financial result.

Therefore, the development of documentation, accounting and analytical support of the reverse costing method, accounting and adjustments of actual costs, as well as the corresponding algorithms, will increase the efficiency of enterprises and the reliability of the reflection of financial information.

The need to carry out transactions related to the adjustment of actual costs has created the prerequisites for the development of a set of accounting and analytical procedures for the reverse costing method, accounting and adjusting the costs of the activities of organizations of the defense industry.

If the products which must be produced under the state defense order have no analogues in the Russian market or are an innovation, the initial price of the contract is determined based on the analysis of settlement prices determined taking into account the results (feasibility studies) of research and experimental design work on creation of analogues of the specified samples (products, materials) and using manufacturers' indexes for the corresponding goods (works, services).

Thus, in case of determining the initial price of a product contract, based on an analysis of settlement prices for analogs or basic developments, using indexes and complexity factors, the initial price of the contract does not reflect the real value of the output and the actual production capacity of the executing organization, but reflects a subjective view customer for the cost of production.

To conclude a contract within the framework of the state defense order, the enterprise must provide a justification for the cost of the items under this contract. In case the actual level of costs under the contract is lower than the planned costs, the contract value is adjusted, as well as the decrease in gross profit.

In these conditions, the enterprise needs to develop accounting and analytical support, which makes it possible to achieve:
1) the optimum cost price of works by definition of the planned level of the items of expenses, closest to the production needs of the executing organization;

2) the maximum possible value of the contract, that is, optimal revenue;

3) maximum possible gross profit under the contract

Taking into account the fact that the above-mentioned indicators affect the overall profitability of the organization, the accounting and analytical support provided below will be a tool that increases the profitability of the executing company.

Analysis of the activities of enterprises within the framework of the state defense order allowed the authors of this scientific research to develop an algorithm for determining the composition of costs under a state contract by the return calculation method, based on the price of work determined by the customer.

Thus, the following problems occur.

Firstly, the level of profitability under a government contract may differ from the profitability, which is independently established by the organization that carries out the defense order in the course of its financial and economic activities.

Secondly, enterprises that are the only possible executors of the state defense order have no right to refuse to fulfill it, as a result of which they must conduct measures to form the cost of production and its components, based on the declared quantities, and take steps to bring the real level of profitability to the values declared by the state.

Thirdly, the enterprise is fully accountable to the state customer for the costs incurred as part of the implementation of the defense order, and has no possibility of misusing the funds allocated by the defense order.

Fourthly, the organization can not raise the level of gross profit. This is due to the fact that when a defense order is executed, profit is calculated as a dependence on costs incurred in the performance of the contract or is fixed, and the product price is calculated as the sum of actual costs and profits, depending on their level or remains unchanged. This means that when the level of costs decreases, the price of the product also decreases, whereas in the case of the production of civil products, the contractor, reducing his level of costs, receives additional profit.

Thus, there are problems in developing such contract calculation that would ensure an acceptable combination of the value of the contract and gross profit for two subjects of economic relations - the customer and the enterprise, in the development of a cost accounting method that would enable full reporting to the customer.

Planning, in which the manufacturing company is forced to accept a limited price for its products, will be called directive. 


\section{APPLICABILITY}

Issues of the directive planning are considered in publications [1, 2, 3-12]. However, the calculation issues of the directive planning are considered not so deep. Besides these article authors' works $[11,12]$, there is no information found in available data sources.

Among the modern calculation methods that are intended to «work» with the preliminary stated financial results, the Target costing system, as well as the backflush approach, can be marked.

Target costing [13] is used at the stage of the product innovation design or modernization of the obsolescent production.

The basis of its idea is the concept of the targeted cost value. Target costing considers the cost value not as the index number that is calculated in accordance with normatives beforehand, but as the value that organization should be aimed at to bring the competitive product to the market. The research work [14-16] describes the application of this backflush approach that is used in the Just-in-Time system, when the production costs are expensed to the cost value of the output production only if its realization, that allows to avoid the presence of the unfinished production and to ease operations' accounting records.

Nevertheless the backflush approach and the Target Costing method are expenses' control systems and do not disclose calculation approaches for the volume of costs that are included in the production prime cost and also do not reflect ways of cost accounting.

In terms of the enterprise operation with the limited production price, there should be a method reflecting the relevant peculiarities of price formation and allowing one to provide the costs' account on this order. The authors' research objective is development of the calculation algorithm of product during directive planning approach of the industrial enterprise activity. Such approach of the cost certification is called "the backflush calculation approach" because the price formation for product starts not from the costs, required for its output, but from the price that is limited by various conditions.

\section{STUDY ASSUMPTION}

A contractor enterprise is obliged to provide the customer with the costing of expenditure items by order. In case the actual level of costs in terms of the contract is lower than specified by the contract, there is a cost correction by the contract and lessening of the gross profit that depends on costs.

In these conditions, the enterprise is to develop the accounting and analytical procurement that allows reaching:

1) the most suitable gross price works by means of definition of the plan level of the expenditure level that is closely related to the operational needs of the contractor organization;
2) maximum possible contract price that means the most preferable operating revenue;

3) maximum possible gross profit by the contract.

Enterprise activity analysis in terms of the directive orders execution allowed authors of these research works to develop the calculation algorithm at a directive price of production.

Costs calculation at a directive price as any private scientific method is based at set of study assumptions. Authors' long-term practice in the sphere of directive planning allows making a professional judgment that the algorithm of expenditures' forming without any damage for the study validity can be formed on the basis of the following assumptions:

1) basing on the methods' classification for the output production calculation, there allowed the use of actual and normative values;

2) in terms of the calculation approach that is being developed, the normative equated interest of the burden costs is calculated as the ratio of the planned total mass of burden costs to the planned base of allocation. In terms of this research, the authors foresee the allocation of the general economic and general production burden costs prorated to the main wage fund of direct workers. Such assumption is determined by the fact that the use of the calculation approach at enterprises, executing the directive orders in the vast majority of cases is provided in terms of the custom-made output and; in this case such burden costs' allocation method is preferable;

3 ) in terms of the directive order execution, the profit received as a result of work fulfillment, can be fixed or calculated as a dependence on costs. During the development of calculation approach at a directive price for the product, it is commonly believed that the profit is the dependence on costs and should be calculated as the ratio of the norm coefficient of the cost effectiveness to the own costs. This can be understood as the full cost of production of work, excluding purchased integrated parts (blanks) and works (services) of other contractors that take part in contract execution. These are means from the sum of the wages fund of the direct labors, social expenditures taken from the wages fund of the direct labors and burden costs that are defined in ratio with the wages fund of the direct labors;

4) material cost, components' cost, subcontract works and works executed by the external companies that is considered in the contract cost - is the minimal one.

\section{DIRECTIVE PRICE STRUCTURE}

The contract price structure at a directive price on production includes the following indexes:

1) the sum of the following expenditure items:

- $\quad$ the wages fund of the direct labors; 
- allocations of the social expenditures taken from the wages fund of the direct labors, calculated as the product of the wages fund of the direct labors cost and the norm coefficient of the social expenditures;

- burden costs that are calculated as the product of the wages fund of the direct labors cost and the norm coefficient of the burden costs;

- material expenditures, equipment and the other production and non-production expenditures;

2) profit that is calculated as the product of the norm coefficient and the sum of the own costs;

3) value added tax and/or the other tax allocations taken from earning and calculated as the percent established by the legislation, multiplied by the sum of expenditures including the profit received by the contract.

In that way, the product price structure (initial contract price) includes:

- the wages fund of the direct labors;

- social expenditures' ratio of the wages fund of the direct labors;

- the burden costs ratio (general economic and general production) of the main wage fund of direct workers;

- cost effectiveness of own costs' ratio;

- taxes and charges percentage rate of earnings and value added tax;

- material expenditures, equipment and the other production and non-production expenditures;

The authors of the paper [11] present the corresponding calculations' formula.

\section{THE DIRECT LABORS' WAGES FUND}

The main calculation element is the dependence of the sundries accounts on the expenditure item "The direct labors' wages fund". Having define the amount of this expenditure item, one can shift to the calculation of the sundry accounts.

To define the direct labor's wages fund, it is necessary to calculate the volume of own costs of the enterprise on this contract. For this purpose, it is necessary to do the following:

1) to define the contract price without taxes, charges and value added tax;

2) to exclude from the contract price expenditures on non-monetary physical things

When maximum own expenditures are fixed, it is necessary to evaluate the direct labors wages fund. It is calculated as the ratio of the own expenditures' mass to the sum of indexed that depend on the wages fund [11].
It is necessary to compare the calculated amount of the direct wages fund that is foreseen by the initial contract price with actual production capabilities of the contractor enterprise that executes the directive order.

For this purpose, it is necessary to define the sufficient (in actual figures) amount of the direct labor wages fund for execution of works by the contract. Methods of the wages fund calculation are specified for each concrete enterprise and do not influence the consistency of the suggested method.

Further, it is necessary to provide the estimation of correlation of the wages fund that is fixed in the inner price of order with the actual necessary wages fund of the direct labor. This correlation obviously demonstrates:

1) which part of expenditures is used for the actually required wages fund that is paid back by assets, included into the initial price of the order for the direct labor wages fund;

2) which following actions are to be taken by the contractor enterprise in terms of the order execution. Authors' long time experience of work in terms of the directive planning allows recommending these actions in the following way. In case of the mentioned above correlation, which is close to unity of the enterprise, which provides measures on documents' preparation for the contract conclusion. When the correlation is different from unity, the assets, included into the initial contract price for the direct labor wages fund, do not reflect the real production potential, it is necessary to provide the correction of the initial price structure by methods contained in this publication [11], considering the actual required wages fund of the direct labor.

Taking into account the grounds provided by the executor, if the correlation of the wages fund, included into the initial contract price with the actually required wages fund of the direct labor, is higher than 1, the contract price should be corrected by the customer to the lower side. If this correlation is less than 1 , the contractor having the grounding can ask the customer to raise the contract price. In case the customer satisfies the contractors' request, the initial contract price is raised up to the sum suggested by the contractor. In case parties of the future contract fail to agree one increase of prices, there is no deal.

The practice shows that in case the customer declines the contractor's initiatives, the enterprise either abandons work fulfillment or executes works on the stipulated terms. Considering the fact that the contractor enterprise is to execute the directive order if they are the unique performer of the work or natural monopoly holders, the contract agreement on unfavorable conditions for the enterprise is rather expectable.

\section{MEASURES ON ACHIEVING THE INITIAL CONTRACT PRICE}

Basing on abovementioned information, the contractor enterprise is to provide measures on reduction of all the 
possible expenditure items to receive the initial contract price. The main measures are aimed at reduction of expenses on the wages fund of the direct labor and adjusting to the level of the fundings, allocated in the initial contract price for these purposes.

Methods of the wages fund of the direct labor reduction are well known; that is why they are not analyzed in this research work.

After implementation of methods of the wages fund of the direct labor reduction, the contractor enterprise receives the appropriate monetary contract characteristics.

In this way, the most appropriate for the enterprise that executes the order with the directive price is the calculation on the contract which allows one to fulfill the following conditions:

1) the initial contract price is calculated on the basis of expanses for the required wages fund of the direct labor;

2) the price of the purchased real assets, contractors' services and works executed by the external organizations is minimal because the less the expenditures on these items are, the more assets are distributed to the own costs of the enterprise;

3) wages fund of the direct labor costs are adjusted closer to the volume of assets that are included into the initial government contract price for these purposes. If the wages fund of the direct labor is less than assets that are included for these purposes, the contract price should be reduced, which means that earnings received because of the contract fulfillment and the mass of profit that depends on the fund. In other words, profitability indexes of the enterprise activity are reduced.

In case conditions grounded in this article are fulfilled the enterprise will achieve the maximum possible profit indexes, earnings and optimum costs' level, which in its turn will provide the defrayal of all the production costs.

\section{PRACTICAL SIGNIFICANCE AND IMPLEMENTATION RESULTS.}

The developed method of the contract price formation in case of limitation of its cost is successfully implemented in the system of the scientific and industrial enterprises of the defense industry complex of the Russian Federation.

This method provides the suitable combination of the contract price and the gross profit for both the subjects of economic activity - the customer and the enterprise.

\section{VIII.CONCLUSIONS}

The research provided by the authors of the article makes a scientific contribution to the evolution of the backflush calculation approach and calculation of production costs that has various limitations of its market price.

Besides, the developed method allows one to execute the actual cost accounting till the moment of the accounting reporting period and correction of financial results basing on customers' conclusions. In this study, the authors have developed a framework of application of the method of backflush calculation.

\section{References}

[1] N.F. Arkhipov, D.N. Bakhanovich, G.A. Lavrinov, State regulation of prices for products for defense purposes. Voennayamisl, no. 12, pp. 25-30, 2007.

[2] V.M. Burenok, Methodical approach to justification and the allocation of funding for the development of weapons systems. Voennayamisl, no. 4, pp. 34-37, 2006.

[3] Zakimatov G.V. Central Directive planning to a market economy - the new economic paradigm. Economikaiupravlrniye, no.6 (104), pp.66$72,2014$.

[4] Koltakov O.V. About the necessity of improving the methodologica apparatus of pricing of military products in terms of determining overhead costs. Voorudjeniyeiekonomika, no. 4(12), pp. 52-56, 2010.

[5] D.A. Kornilov, A.S. Sakharov, Analysis and development of methods of strategic planning in Russia and abroad.Economikaipredprinimatelstvo, no.6-1 (59-1), pp. 618-622, 2015.

[6] V.V. Kurnosov, Planning socio-economic development of Russia based on the experience of the USSR. Moscow: Vestnik VEGU, no.3, pp. 36-41, 2011.

[7] Lavrinov G.A., Podolskiy A.G., KhrustalyevE.Yu.Analysis of the factors influencing the pricing of military products.Finansovayaanalitika: problem iresheniya, no. 28 , pp. $2-8$, 2012.

[8] G.A. Lavrinov, A.G. Podolskiy, E.Yu. Khrustalyev, The concept of constructing a system of internal pricing for military products.Finansovayaanalitika: problem iresheniya, no. 29, pp. 2-9, 2012.

[9] P.A. Marichev Methodological apparatus of substantiation of the initial price of the contract for development of weapons and military equipment of antiaircraft defense based on the possible financial losses of the customer. Voorudjeniyeiekonomika, 2010, no. 4 (12), pp. 45-51 (in Russia).

[10] MetovA.Kh. Analysis of system violations in the sphere of pricing on NIOKR by the state defensive order. Under edition Vernigora A.P. Moscow: Krasnaya Zvezda, 2014, 420 p

[11] A.F. Chernenko, O.A. Afonina Reverse costing and cost accounting at the enterprises of the military industrial complex. Mejdunarodniybukhgalterskiyuchet, no. 11 (257), pp. 16-29, 2013.

[12] A.F. Chernenko, O.A. Afonina Organization of application of method of back-calculation (part 1). Mejdunarodniybukhgalterskiyuchet, no. 25 (271), pp. 18-30, 2013.

[13] Hiromoto T. Another hidden-Japanese Management Accounting.Harvard Business Review, 1988. pp. 4-7.

[14] E.Yu. Voronova, Costing method return writeoff.Auditorskiyevedomosty, no. 8, pp. 56-66, 2007.

[15] I.A. Maslova, S.S. Prozorova, Management accounting overheads: the application of the method JIT (JUST-IN-TIME) and the ABC method [Electronic resource]. Upravlencheskiyuchet, 2006, no 4. URL: http://www.upruchet.ru/articles/2006/4/4584.html.

[16] K.V. Schiborsch, Budgeting activity of the industrial enterprises of Russia.Moskow: Delo I service, 2001, 544 p. 
